\title{
The Sam D. Carpenter Bottom Site (41CP495) in the Big Cypress Creek Basin, Camp County, Texas
}

Timothy K. Perttula

Heritage Research Center, Stephen F. Austin State University

LeeAnna Schniebs

Follow this and additional works at: https://scholarworks.sfasu.edu/ita

Part of the American Material Culture Commons, Archaeological Anthropology Commons, Environmental Studies Commons, Other American Studies Commons, Other Arts and Humanities Commons, Other History of Art, Architecture, and Archaeology Commons, and the United States History Commons

Tell us how this article helped you.

This Article is brought to you for free and open access by the Center for Regional Heritage Research at SFA ScholarWorks. It has been accepted for inclusion in Index of Texas Archaeology: Open Access Gray Literature from the Lone Star State by an authorized editor of SFA ScholarWorks. For more information, please contact cdsscholarworks@sfasu.edu. 


\section{The Sam D. Carpenter Bottom Site (41CP495) in the Big Cypress Creek Basin, Camp County, Texas}

\section{Creative Commons License}

\section{(c) (1) \&}

This work is licensed under a Creative Commons Attribution-NonCommercial 4.0 International License 


\title{
The Sam D. Carpenter Bottom Site (41CP495) in the Big Cypress Creek Basin, Camp County, Texas
}

\author{
Timothy K. Perttula, with a contribution by LeeAnna Schniebs
}

\section{INTRODUCTION AND SITE SETTING}

Robert L. Turner, Jr. obtained a surface collection of ancestral Caddo material culture remains from the Sam D. Carpenter Bottom site (41CP495) an unknown number of years ago. With records provided by Turner, Bo Nelson has recently recorded the site, and provided the artifacts from the surface collection for analysis.

The Sam D. Carpenter Bottom site (41CP495) is situated on a broad and cleared alluvial fan (280 feet amsl) in the Big Cypress Creek valley (Figure 1), with the Prairie Creek valley not far to the south and the Dry Creek valley not far to the north. There are short, intermittent tributaries to the creek on either side of the alluvial fan, and these flow roughly north and northeast to Big Cypress Creek, the current channel of which is ca. $2 \mathrm{~km}$ to the northeast. The Sam D. Carpenter Garden Plot site (41CP496), a Caddo site of similar age and character, is about $1 \mathrm{~km}$ to the west (Perttula 2013).

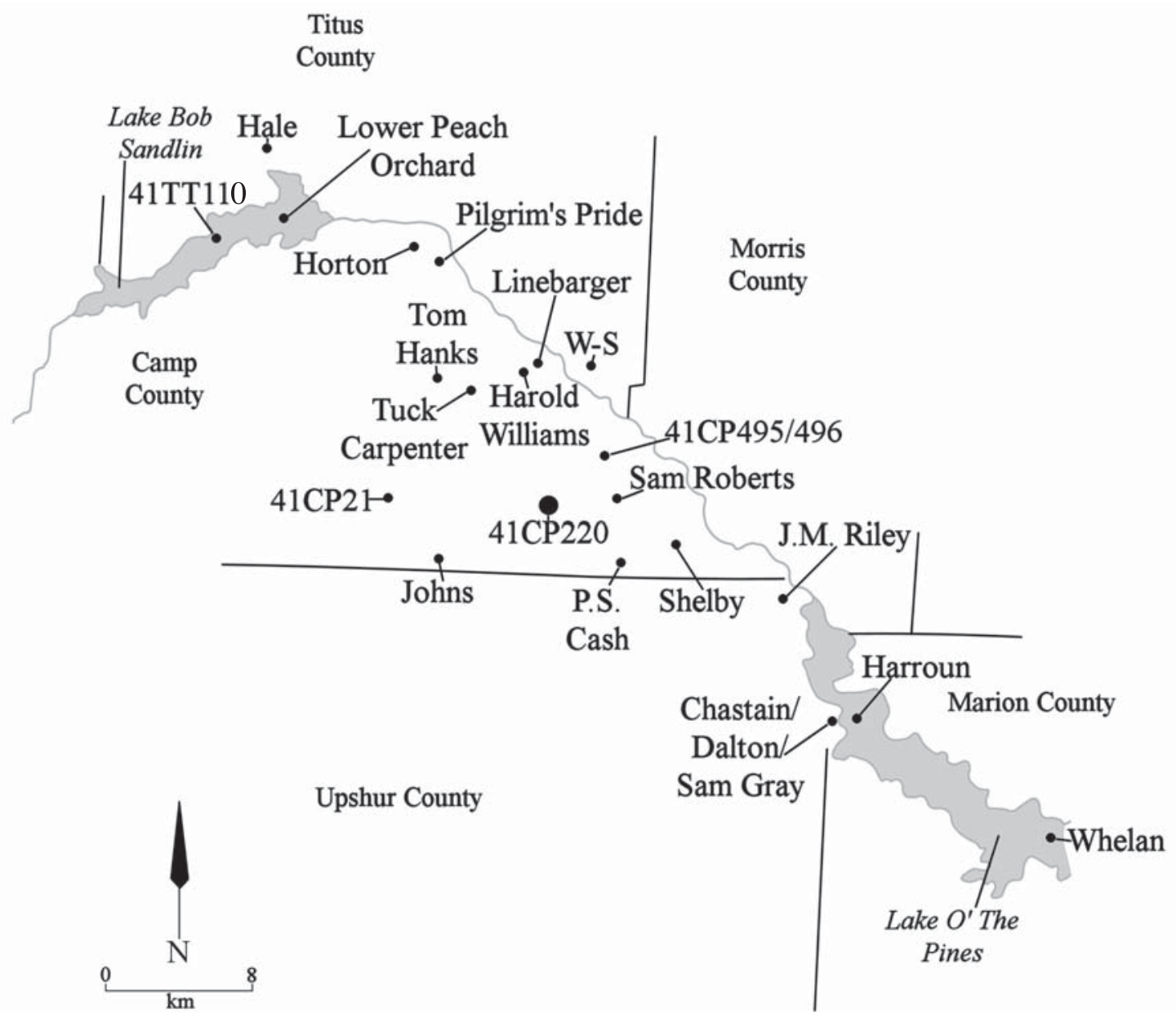

Figure 1. The general location of the Sam D. Carpenter Bottom site in the Big Cypress Creek basin, camp County, Texas. 


\begin{abstract}
ARTIFACTS
The vast majority of the artifacts collected from the Sa, D. Carpenter Bottom site are ceramic sherds $(n=1539)$ from plain wares, utility wares, and fine ware vessels, and there is also a single clay elbow pipe sherd. Lithic artifacts in the collection include several Late Caddo style arrow points, biface fragments, lithic debris and cores, as well as a few ground stone tools. Finally, there are well-preserved faunal remains and mussel shell fragments from the site, and their occurrence is indicative of the preservation of prehistoric midden deposits.
\end{abstract}

\title{
Ceramic Sherds
}

The ceramic assemblage at the Sam D. Carpenter Bottom site is extensive, given that it was gathered from a general surface collection (Table 1). The plain sherds comprise approximately $50 \%$ of the assemblage, $38 \%$ are from the decorated portion of utility ware vessels, and $11.5 \%$ are from slipped and engraved fine ware vessels.

Table 1. Ceramic Assemblage from the Sam D. Carpenter Bottom site.

\begin{tabular}{llllll}
\hline Ware & Rim & Body & Base & N & Percent \\
\hline Plain & 26 & 704 & 45 & 775 & 50.3 \\
Utility & 62 & 524 & - & 586 & 38.2 \\
Fine & 35 & 143 & - & 178 & 11.5 \\
\hline Totals & 123 & 1371 & 45 & 1539 & 100.0 \\
\hline
\end{tabular}

Based on the proportion of rims among the three wares, however, $50 \%$ of the sherds are from utility ware vessels (jars, primarily). Another $21 \%$ are from plain wares (bowls, jars, and carinated bowls), and the remaining 29\% are from fine ware vessels (bowls, bottles, carinated bowls, and compound bowls). The plain to decorated sherd ratio for the assemblage is 1.01, consistent with Late Caddo period, Titus phase occupations in the Big Cypress Creek basin.

The sherds are from vessels primarily tempered with grog (or crushed sherds), ranging from $91.8 \%$ to $93.2 \%$ by ware (Table 2), and grog-tempered sherds account for $92.4 \%$ of the entire sherd assemblage. Bone temper accounts for only between $6.2-8.2 \%$ of the sherds by ware, and two sherds - a plain rim and a red-slipped engraved body sherd - are from vessels made with shell temper. These latter two vessels likely were made either among Caddo groups on the middle Red River (i.e., McCurtain phase) or Belcher phase Caddo groups in the Great Bend area of Southwest Arkansas and Northwest Louisiana (Perttula et al. 2012).

Table 2. Tempers used in the three wares.

\begin{tabular}{lllll}
\hline Ware & Grog & Bone & Shell & N \\
\hline Plain & $92.5 \%$ & $7.4 \%$ & $0.1 \%$ & 775 \\
Utility & $91.8 \%$ & $8.2 \%$ & - & 586 \\
Fine & $93.2 \%$ & $6.2 \%$ & $0.6 \%$ & 178 \\
& & & \\
\hline Totals & $92.4 \%$ & $7.5 \%$ & $0.1 \%$ & 1539 \\
\hline
\end{tabular}




\section{Fine Wares}

The fine ware sherds from the Sam D. Carpenter Bottom site include both engraved and red-slipped sherds (Table 3). A significant portion of the fine wares (13.5\%) are clearly from vessels (bowls and bottles) decorated only with a red slip on one or both vessel surfaces, which is consistent with the use of red slipping among Caddo groups living in the western part of the Big Cypress Creek basin heartland. The remainder of the fine wares are from engraved bottles (9.5\%) and engraved bowls (77.0\%), including bowls, carinated bowls, and compound bowls; about 5\% of these vessel sherds also have a red slip. A small proportion (4.6\%) of the engraved sherds have either a red $(n=5)$ or white $(n=2)$ pigment rubbed in the engraved decoration. This form of decorative embellishment is more prevalent in the bottle sherds (17.6\%) than in the bowl sherds (2.9\%).

Table 3. Fine wares from the Sam D. Carpenter Bottom site.

\begin{tabular}{lllll}
\hline Decorative Method & Rim & Body & N & Percent \\
\hline Engraved, bottle sherds & - & 17 & 17 & 9.5 \\
Engraved & 32 & 105 & 137 & 77.0 \\
Red-slipped & 3 & 21 & 24 & 13.5 \\
\hline Totals & 35 & 143 & 178 & 100.0 \\
\hline
\end{tabular}

\section{Slipped Sherds}

There are rim and body sherds from red-slipped vessels at the site (Figure 2a-f); the slip is made from a clay wash that had crushed hematite or red ochre added to it before its application to the vessel surfaces. These sherds are from bowls (Figure 2a, f) as well as bottles (Figure 2d). Bowls have a red slip on both interior and exterior surfaces $(n=18)$, while bottles have a slip only on the exterior surface $(n=6)$.
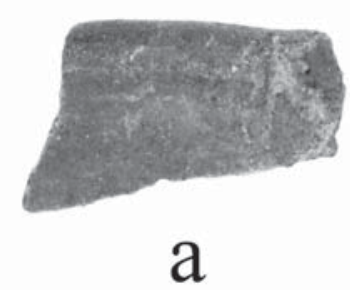

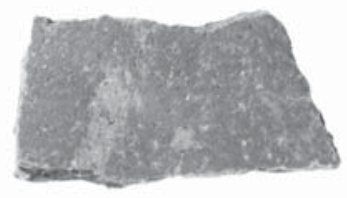

b

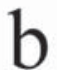

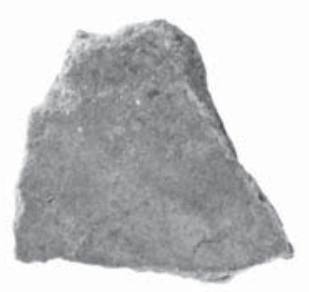

C
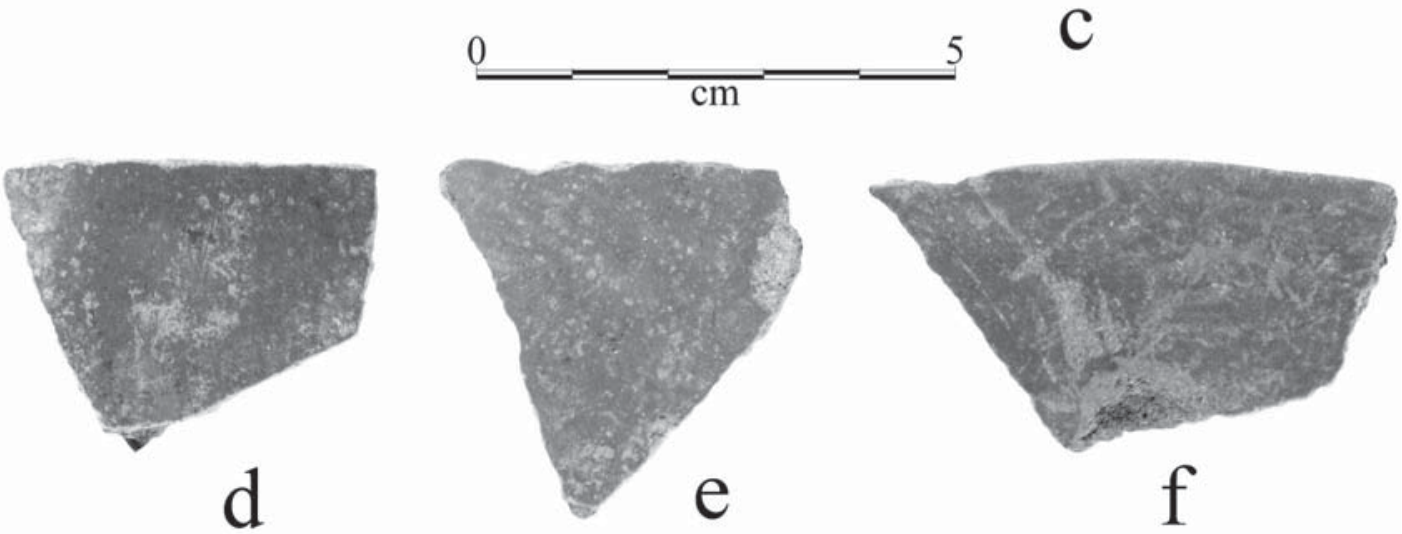

Figure 2. Red-slipped rim and body sherds: a, f, rim sherds; b-e, body sherds. 


\section{Engraved Sherds}

There are 154 engraved rim and body sherds in the Sam D. Carpenter Bottom site ceramic assemblage (see Table 3), including 32 rims. About $11 \%$ of these sherds are from Ripley Engraved bottles (Figure 3). None of the bottle sherds are from red-slipped vessels, but three have a red pigment applied to the engraved decoration (Figure 3a-c).

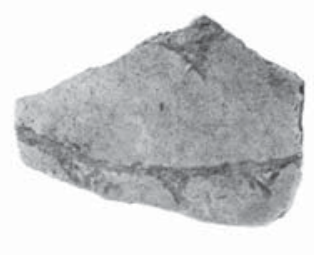

a

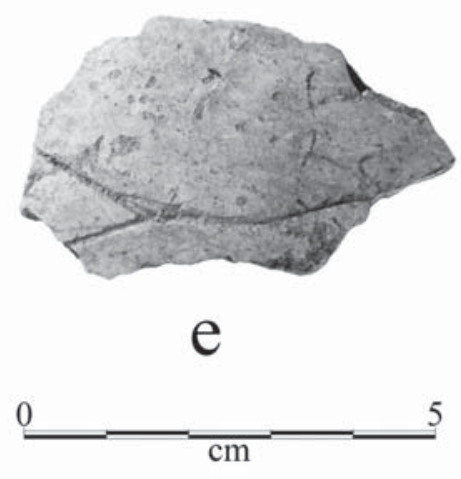

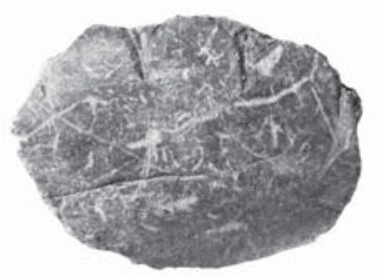

b
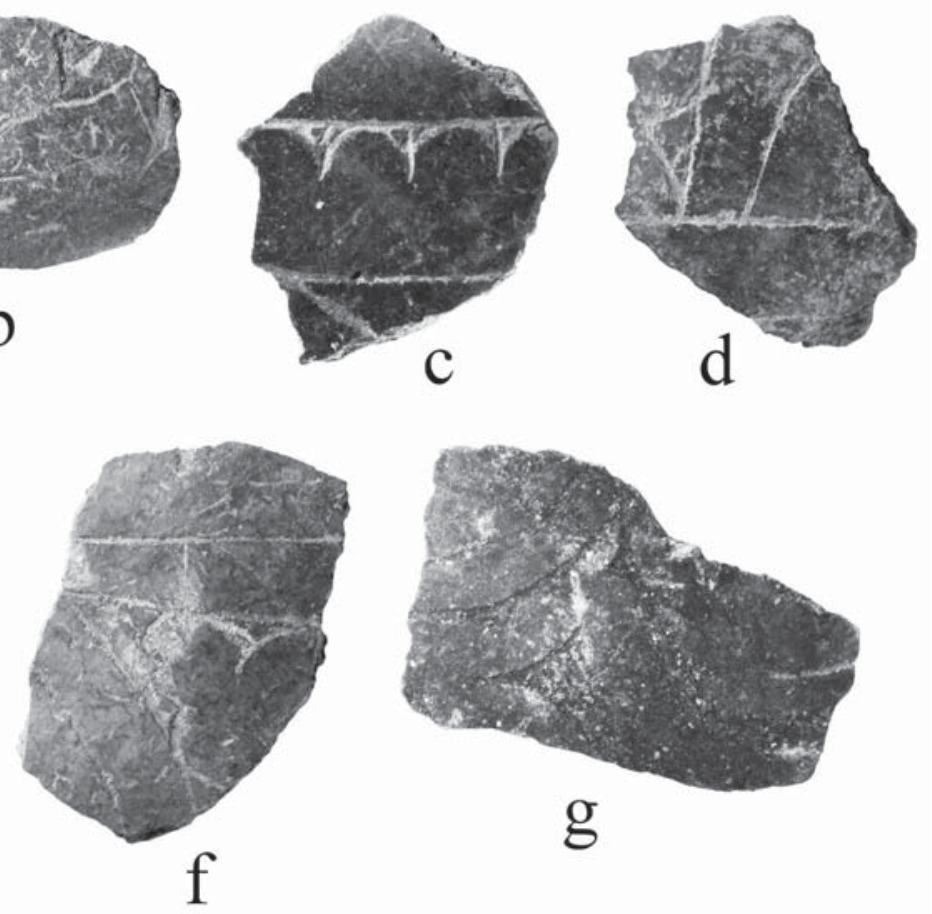

Figure 3. Ripley Engraved bottle sherds.

Many of the Ripley Engraved bottle sherds have curvilinear or straight lines with excised or hatched pendant triangles ( $n=8$, see Figure 3a-d, f-g). Others have curvilinear engraved lines ( $n=8$, see Figure $3 e$ ) or sets of parallel lines on the vessel body, but lack the pendant triangles.

There are a wide variety of engraved elements on sherds from carinated bowls, compound bowls, and bowls in the fine wares (Table 4). In most cases, it appears that these engraved sherds are from Ripley Engraved vessels (see Suhm and Jelks 1962:Plate 64). Ripley Engraved is the principal fine ware in Late Caddo period Titus phase occupations dating from ca. A.D. 1430-1680 in both the Big Cypress and middle Sabine River basins in East Texas (Fields and Gadus 2012; Perttula 2012). The decorative elements recognized in this set of engraved sherds includes circle elements (Figures $4 \mathrm{e}$ and $5 \mathrm{a}, \mathrm{i}, \mathrm{k}$ ), concentric semi-circles, cross-hatched circles and zones (Figures $4 \mathrm{~g}$ and $5 \mathrm{~b}$ ), sets of curvilinear engraved lines and/or curvilinear zones (Figure $5 \mathrm{c}-\mathrm{e}$ ), sets of horizontal engraved or excised lines (many most likely from compound bowls or carinated bowls with horizontal scroll lines, Figure 4a, f), horizontal and vertical engraved lines (Figure 4h), slanted scrolls and scroll dividers (Figures 4c-d and 5f-h), scrolls and circles, semi-circles (Figure 5j), and vertical lines and zones (Figure $4 \mathrm{~b}$, i). There are also a few rim and body sherds that have pendant triangle elements (Figure $4 \mathrm{j}$ ), but these are not representative of the pendant triangle motif defined by Thurmond (1990:Figure 6) on Ripley Engraved vessels. None of the sherds from the site have sets of upper and lower pendant triangles divided by a horizontal scroll line, and there are no central engraved diamond elements recognized in the Sam D. Carpenter Bottom site fine wares, which is one of the principal elements in the pendant triangle motif. 
Table 4. Decorative elements on engraved carinated bowl, compound bowl, and bowl rim and body sherds.

\begin{tabular}{|c|c|c|c|}
\hline Decorative Element & Rim & Body & $\mathrm{N}$ \\
\hline Circle element & 1 & 3 & 4 \\
\hline Circle element and cross-hatched zone & - & 1 & 1 \\
\hline Circle element and hatched zone & - & 1 & 1 \\
\hline Circular zone, hatched & - & 1 & 1 \\
\hline Sub-total, circle elements & 1 & 6 & 7 \\
\hline Concentric semi-circles and excised pendant triangles & - & 1 & 1 \\
\hline Cross-hatched circles & - & 2 & 2 \\
\hline Cross-hatched and diagonal engraved lines & - & 1 & 1 \\
\hline Cross-hatched curvilinear zone & - & 1 & 1 \\
\hline Cross-hatched curvilinear zone and curvilinear lines & - & 1 & 1 \\
\hline Cross-hatched engraved zone & 1 & 5 & 6 \\
\hline Cross-hatched engraved zone and curvilinear engraved line & - & 1 & 1 \\
\hline Cross-hatched zone and parallel engraved lines & - & 1 & 1 \\
\hline Cross-hatched engraved zone and slanted scroll & - & 3 & 3 \\
\hline Cross-hatched engraved zones and vertical engraved line & 1 & - & 1 \\
\hline Sub-total, cross-hatched zones and elements & 2 & 15 & 17 \\
\hline Curvilinear engraved lines & - & 9 & 9 \\
\hline Curvilinear engraved line and excised pendant triangle & - & & 1 \\
\hline Curvilinear engraved lines and open pendant triangle & - & 2 & 2 \\
\hline Curvilinear zone, excised & - & 1 & 1 \\
\hline Curvilinear and hatched zones & - & 3 & 3 \\
\hline Sub-total, curvilinear lines and zones & - & 16 & 16 \\
\hline Diagonal engraved lines & 1 & - & 1 \\
\hline Hatched divider & 1 & - & 1 \\
\hline Hatched zone & - & 3 & 3 \\
\hline Sub-total, hatched elements & 1 & 3 & 4 \\
\hline Horizontal engraved lines & 10 & 4 & 14 \\
\hline Horizontal engraved line and narrow hatched zone & - & 1 & 1 \\
\hline Horizontal engraved lines and hatched triangles & 1 & - & 1 \\
\hline Horizontal engraved line and excised divider & - & 1 & 1 \\
\hline Horizontal engraved scroll & 1 & - & 1 \\
\hline Horizontal engraved scroll and hatched divider & - & 1 & 1 \\
\hline Horizontal excised area & 1 & - & 1 \\
\hline Horizontal engraved lines and slanting scroll & 1 & - & 1 \\
\hline Horizontal and vertical engraved lines & 4 & - & 1 \\
\hline Sub-total, horizontal lines and scroll elements & 18 & 7 & 25 \\
\hline
\end{tabular}


Table 4. Decorative elements on engraved carinated bowl, compound bowl, and bowl rim and body sherds, cont.

\begin{tabular}{|c|c|c|c|}
\hline Decorative Element & $\operatorname{Rim}$ & Body & $\mathrm{N}$ \\
\hline Opposed engraved lines & - & 4 & 4 \\
\hline Parallel engraved lines & - & 10 & 10 \\
\hline Parallel engraved lines and excised pendant triangle & - & 1 & 1 \\
\hline Parallel engraved lines and hatched zone & - & 1 & 1 \\
\hline Parallel engraved lines and open pendant triangle & - & 1 & 1 \\
\hline Sub-totals, parallel lines and elements & - & 3 & 3 \\
\hline Pendant triangle, excised & 1 & - & 1 \\
\hline Pendant triangle, hatched & 1 & - & 1 \\
\hline Sub-total, pendant triangles & 2 & - & 2 \\
\hline Scroll and circle element & 1 & 1 & 2 \\
\hline Scroll engraved element & 1 & - & 1 \\
\hline Scroll engraved divider & 1 & - & 1 \\
\hline Scroll fill zones & - & 4 & 4 \\
\hline Scroll, slanting & 3 & 5 & 8 \\
\hline Sub-total, scrolls & 6 & 10 & 16 \\
\hline Semi-circle element & - & 1 & 1 \\
\hline Straight engraved line & - & 24 & 24 \\
\hline Straight engraved line and excised pendant triangle & - & 1 & 1 \\
\hline Sub-total, straight lines & - & 25 & 25 \\
\hline Vertical engraved lines & - & 1 & 1 \\
\hline Vertical hatched zone and horizontal engraved line & 1 & - & 1 \\
\hline Sub-total, vertical lines and elements & 1 & 1 & 2 \\
\hline
\end{tabular}

It appears to be the case that the engraved carinated bowl sherds are primarily from Ripley Engraved vessels with scroll and scroll and circle motifs, as well as scrolls with semi-circle motifs, seen on ceramic vessels from early Titus phase mortuary contexts in the western part of the Big Cypress Creek basin. There are other Ripley Engraved sherds in the collection with portions of horizontal scrolls, or with vertical engraved lines that may mark portions of a continuous scroll motif. Scroll dividers are hatched, cross-hatched, or excised (see Figure 4b, d-e), as are scroll fill zones (i.e., the zones above and below the central scroll line, see Figures $4 d$ and 5f-g).

The one bowl rim has a single row of hatched pendant triangles under the lip (see Figure 4j). Identified compound bowl sherds have widely-spaced horizontal engraved lines on what would be the rim's upper panel (see Figure 4f). It is not known what decorative motifs would have been present on the lower rim panel. 


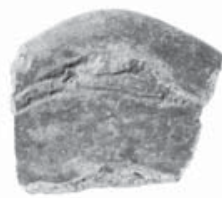

a

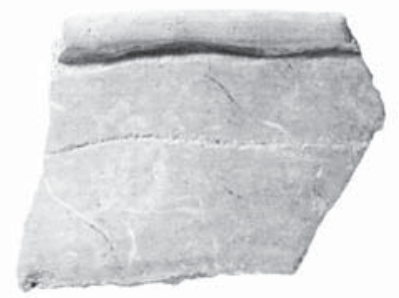

f

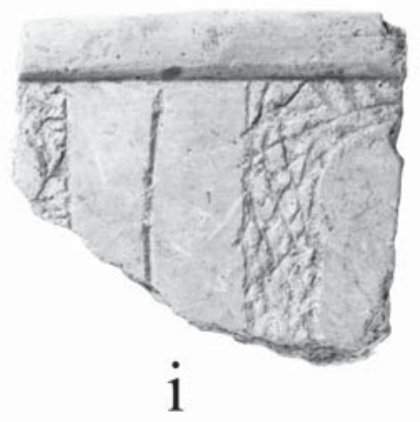

0

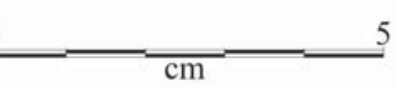

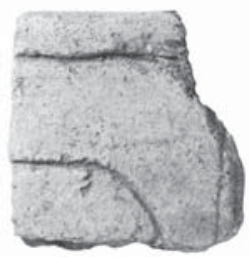

c

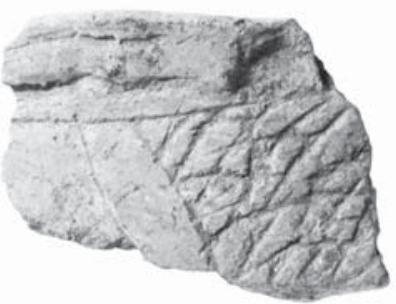

$\mathrm{g}$

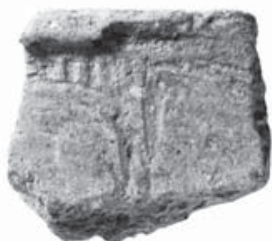

d

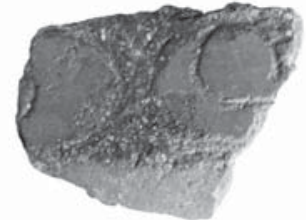

e

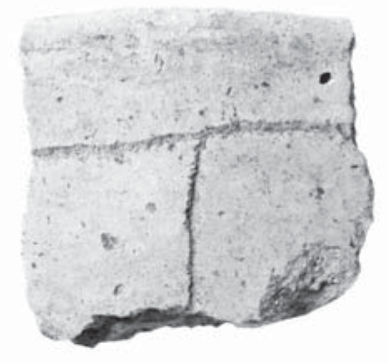

$\mathrm{h}$

Figure 4. Engraved carinated bowl, compound bowl, and bowl rim sherds: a-e, g-i, carinated bowl; f, compound bowl; j, bowl.

Eight engraved carinated bowl rim and body sherds also have an interior and exterior red slip. Two have portions of Ripley Engraved scroll elements, while the others have horizontal, parallel, or straight lines, circle elements (see Figures 4e and 5a), or a horizontal excised area on a vessel with a rim peak (see Figure 4a). The red-slipped body sherd with a straight engraved line is shell-tempered; it likely is from an Avery Engraved red-slipped vessel.

\section{Utility Wares}

The utility ware sherds at the Sam D. Carpenter Bottom site are dominated by vessels with brushing on the rim and/or the body of cooking and storage jars (Table 5). Sherds with just brushing comprise $63.5 \%$ of 


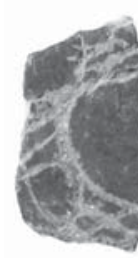

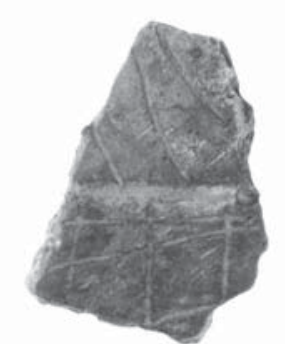

b

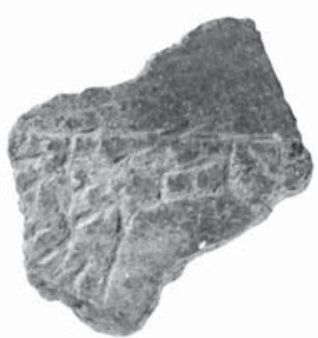

C

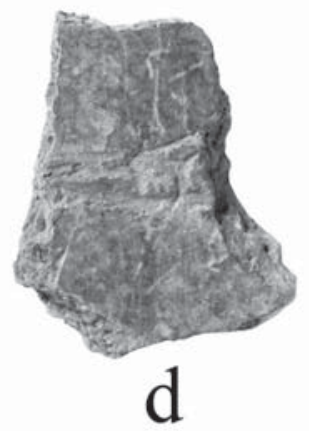

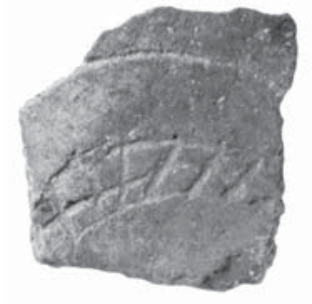

e

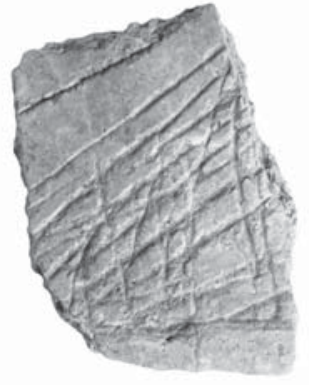

$\mathrm{f}$

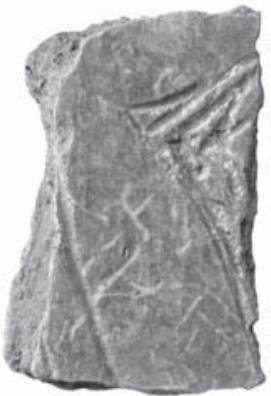

g

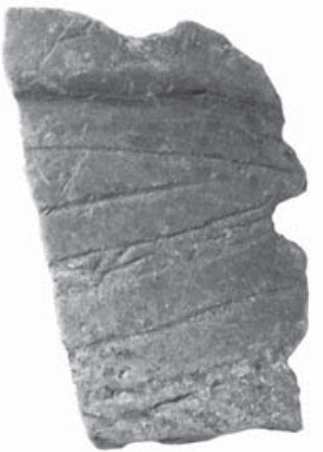

$\mathrm{h}$

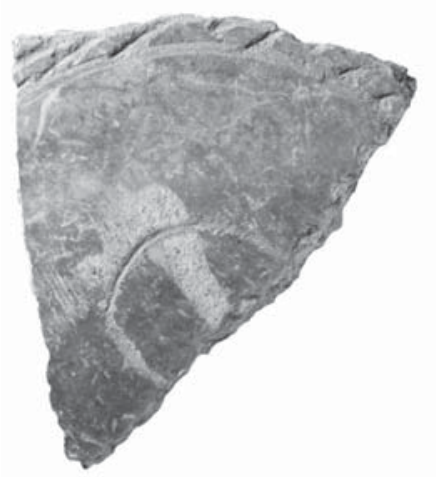

i

0

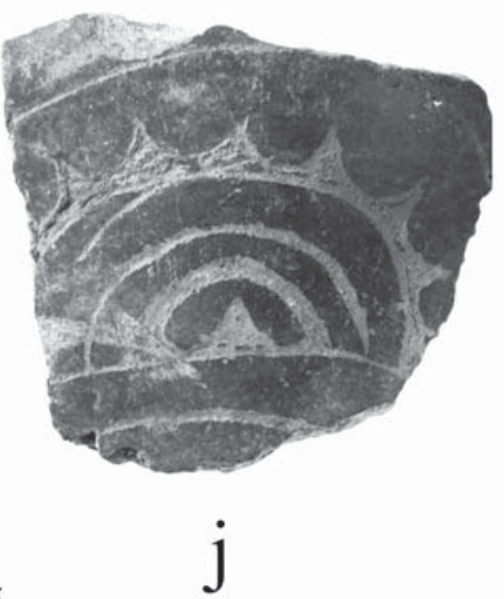

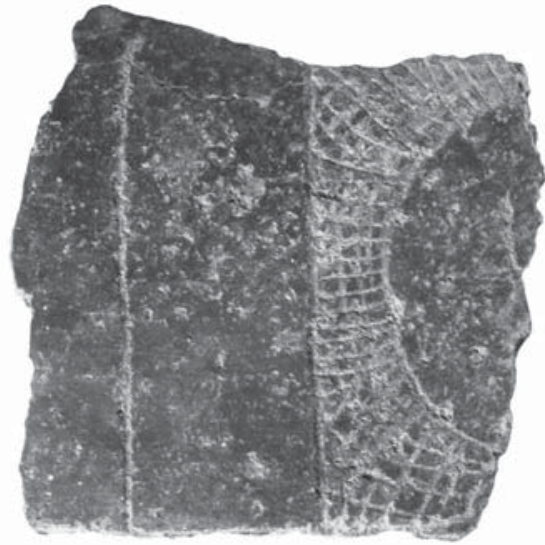

$\mathrm{k}$

Figure 5. Engraved carinated bowl body sherds.

the utility ware assemblage, and another 5.5\% have brushed decorations in combination with other decorative methods. More than $27 \%$ of the utility ware rims are from brushed vessels.

Other important utility wares include vessel sherds with incised $(20.5 \%$ of the utility wares and $37 \%$ of the utility ware rims) and punctated (6.0\% of the utility wares and $19 \%$ of the utility ware rims) decorations 
Table 5. Utility wares at the Sam D. Carpenter Bottom site.

\begin{tabular}{|c|c|c|c|c|}
\hline Decorative Method & Rim & Body & $\mathrm{N}$ & Percent \\
\hline Appliqued & 2 & 6 & 8 & 1.4 \\
\hline Appliqued-Incised & - & 5 & 5 & 0.9 \\
\hline Brushed & 15 & 357 & 372 & 63.5 \\
\hline Brushed-Appliqued & - & 3 & 3 & 0.5 \\
\hline Brushed-Appliqued-Incised & - & 1 & 1 & 0.2 \\
\hline Brushed-Appliqued-Punctated & - & 1 & 1 & 0.2 \\
\hline Brushed-Incised & - & 20 & 20 & 3.4 \\
\hline Brushed-Punctated & 2 & 5 & 7 & 1.2 \\
\hline Incised & 23 & 97 & 120 & 20.5 \\
\hline Incised-Punctated & 7 & 3 & 10 & 1.7 \\
\hline Incised-Punctated-Brushed & - & 1 & 1 & 0.2 \\
\hline Neck Banded & 1 & 1 & 2 & 0.3 \\
\hline Punctated & 13 & 22 & 35 & 6.0 \\
\hline Ridged & - & 1 & 1 & 0.2 \\
\hline Total & 63 & 523 & 586 & 100.0 \\
\hline
\end{tabular}

(see Table 5). Sherds with appliqued decorations comprise $2.3 \%$ of the utility wares; $1.9 \%$ have incisedpunctated decorations; and there are also a very few neck banded and ridged sherds (see Table 5).

\section{Brushed Sherds}

Brushed sherds, probably from Bullard Brushed jars and other types that have brushing on their vessel bodies, comprise almost $64 \%$ of the utility wares at the Sam D. Carpenter Bottom site (see Table 5). The proportions of brushed utility ware sherds is consistent with a Late Caddo period Titus phase occupation in the Big Cypress Creek basin in East Texas. All rims with brushing have horizontal brushing marks (Figure 6a-d), including several from vessels with bone temper.

The brushed body sherds have parallel ( $n=337$, Figure $7 \mathrm{a}-\mathrm{d}, \mathrm{g}, \mathrm{k}-\mathrm{l})$, opposed ( $\mathrm{n}=5$, Figure 7e), overlapping $(n=5)$, vertical ( $n=9$, Figure 7i) brushing marks, as well as one body sherd with a zone of curvilinear brushing marks (Figure 7h). It is likely that the majority of the parallel brushed sherds actually have brushing marks that are oriented vertically on the body of utility ware jars.

\section{Brushed-Incised Sherds}

There are a few $(\mathrm{n}=20)$ body sherds - all grog-tempered - that have brushed and incised decorative elements. This includes 18 with parallel brushed-incised lines (see Figure 7f, j), one with vertical brushed-incised lines, and another body sherd with diagonal incised lines adjacent to an area with horizontal brushing marks. 

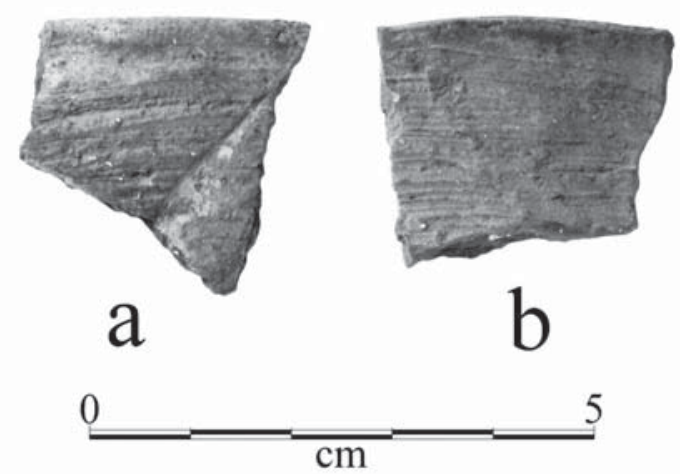

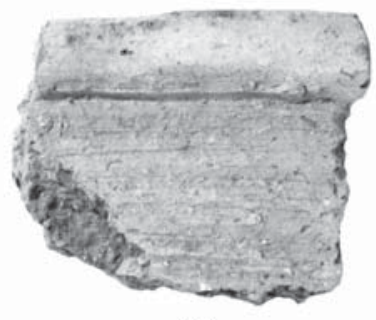

C

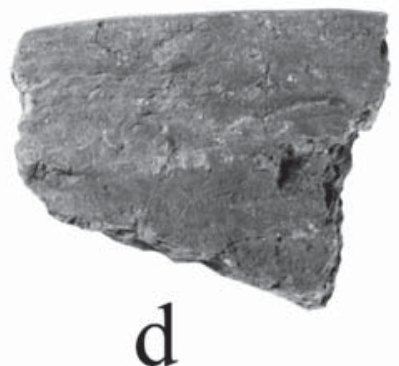

Figure 6. Horizontal brushed rim sherds: a-c, bonetempered rims; d, grog-tempered rim.

\section{Brushed-Punctated Sherds}

The grog-tempered brushed-punctated sherds represent $1.2 \%$ of the utility wares in the Sam D. Carpenter Bottom assemblage (see Table 5). The two rims have horizontal brushing with horizontal rows of tool punctations near mid-rim. Body sherds have a row of tool punctations at the rim-body juncture (Figure 8b), with diagonal or vertical brushing on the vessel body itself. Other body sherds have parallel or horizontal brushing marks adjacent to a row or rows of tool punctations (Figure 8a).

\section{Incised Sherds}

Sherds from incised utility wares comprise the second-most important set of sherds in the assemblage, comprising $20 \%$ of all the utility ware sherds and more than $36 \%$ of the utility ware rim sherds (see Table 5). These sherds are primarily from Maydelle Incised vessels. There are a number of different decorative elements on the incised rim and body sherds (Table 6).

On the rim sherds, the most common decorative element is sets of diagonal incised lines (Figure 9c, g), followed by opposed sets of incised lines (Figure 9b, e, h). Other decorative elements on the rims include cross-hatched lines (Figure 9d), horizontal incised lines, diagonal and opposed incised lines (Figure 9f), and horizontal and vertical incised lines (Figure 9a).

Table 6. Decorative elements on incised rim and body sherds from the Sam D. Carpenter Bottom site.

\begin{tabular}{llll}
\hline Decorative Element & Rim & Body & N \\
\hline Cross-hatched incised lines & 2 & 3 & 5 \\
Curvilinear incised lines & - & 1 & 1 \\
Curvilinear incised lines and cross-hatched incised zone & - & 1 & 1 \\
Diagonal incised lines & 12 & 3 & 15 \\
Diagonal and horizontal incised lines & - & 1 & 1 \\
Diagonal and opposed incised lines & 1 & - & 1 \\
Diagonal and vertical incised lines & $*$ & $*$ & 1 \\
Horizontal incised lines & 3 & - & 3 \\
Horizontal and vertical incised lines & 1 & - & 1 \\
Opposed incised lines & 4 & 8 & 12 \\
Parallel incised lines & - & 62 & 62 \\
Parallel and curvilinear incised lines & - & 1 & 1 \\
Straight incised line & - & 14 & 14 \\
Vertical incised lines & - & 1 & 1 \\
Vertical and opposed incised lines & - & 1 & 1 \\
\hline
\end{tabular}

*diagonal incised lines on the rim and vertical incised lines on the body of one sherd 


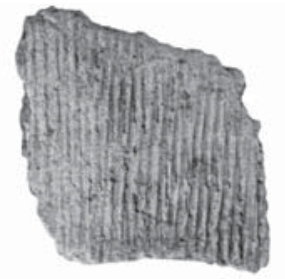

a

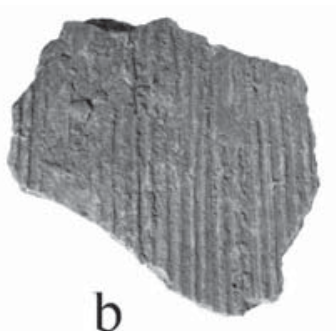

b

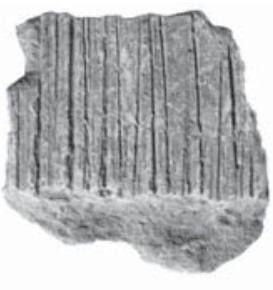

c

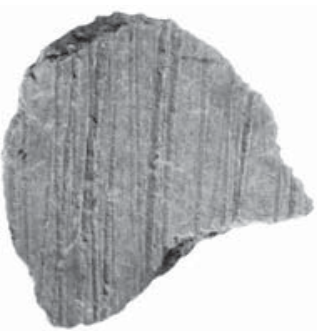

d

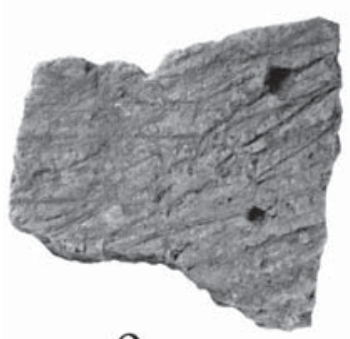

e
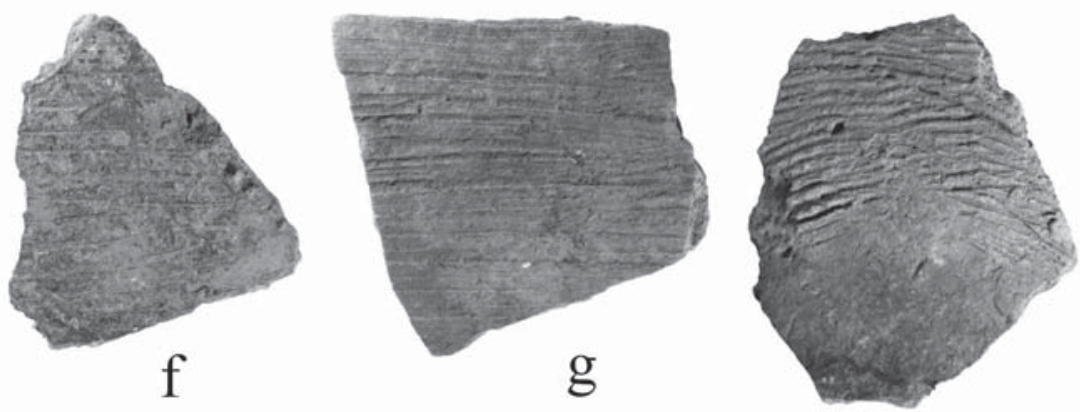

$\mathrm{h}$
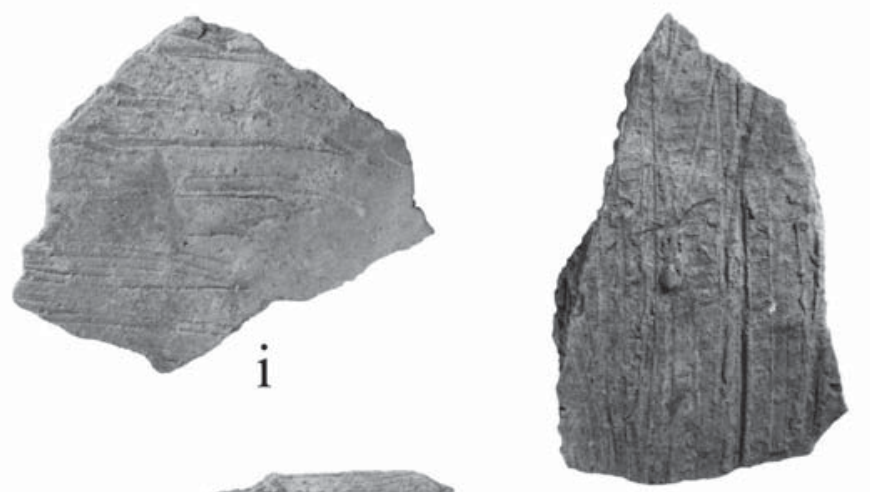

$\mathrm{j}$
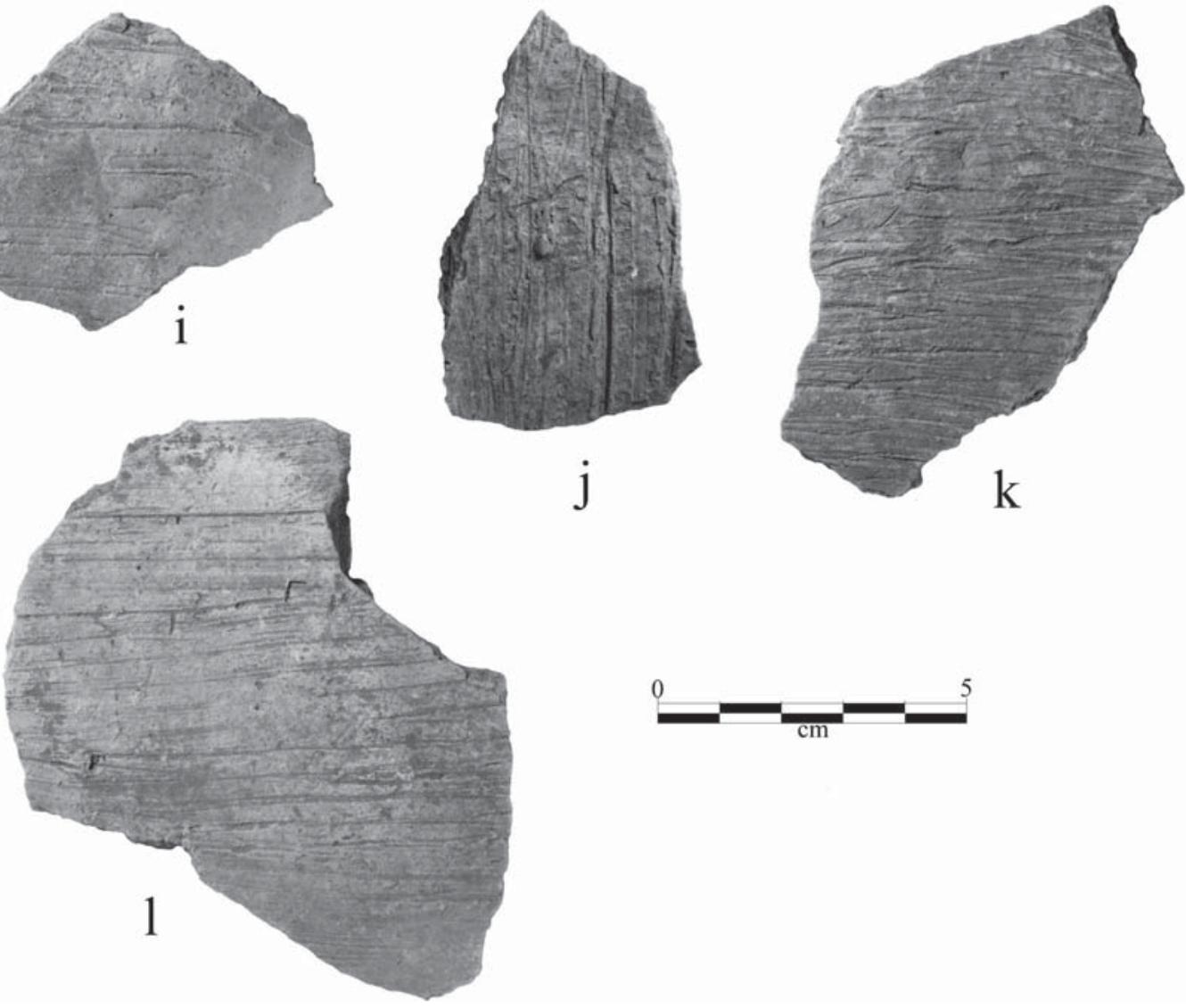

Figure 7. Brushed and brushed-incised body sherds: a-e, g-i, k-1, brushed body sherds; $\mathrm{f}, \mathrm{j}$, brushed-incised. 


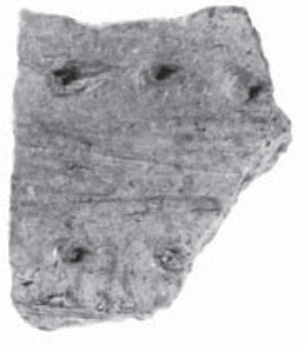

a

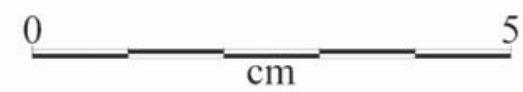

The majority of the body sherds have sets of parallel incised lines, where the orientation of the lines on the vessel is unknown (Figure 10d, h), or a single straight incised line (see Table 6). Other body sherds have opposed incised lines (Figure 10e-g), cross-hatched (Figure 10b), diagonal, and vertical incised lines (Figure 10c), among other decorative elements. One body sherd is from a Pease Brushed-Incised jar (see Suhm and Jelks 1962:Plate 60k) with opposed sets of incised lines radiating from a single vertical incised line (Figure 10a); the vertical incised line defines a panel filled with the opposed incised lines.

Figure 8. Brushed-punctated body sherds.

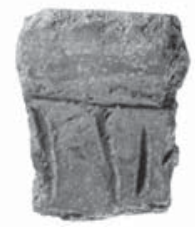

a

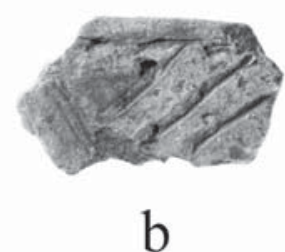

b

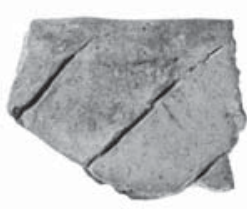

C

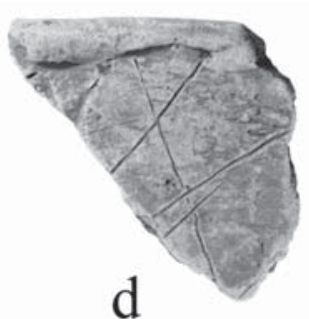

d

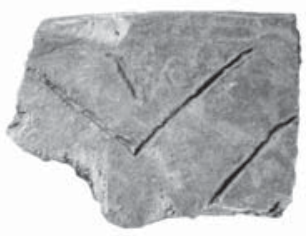

e

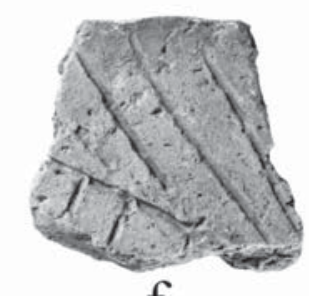

f

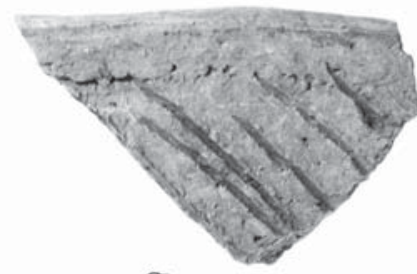

g

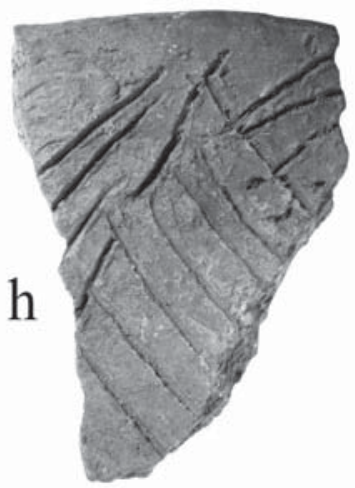

Figure 9. Incised rim sherds from the Sam D. Carpenter Bottom site.

\section{Punctated Sherds}

Sherds with punctated decorative elements are an important part of the utility ware assemblage at the site, comprising $6 \%$ of the surface collection sample and approximately $20 \%$ of the utility ware rims. The rim sherds have rows (both horizontal and diagonal in orientation) of tool punctations ( $\mathrm{n}=11$, Figure 11a-d, f) and circular tool punctations ( $\mathrm{n}=2$, Figures 11e and 12c). Body sherds have tool punctated rows ( $\mathrm{n}=17$, Figure 12a-b, d-e, g), circular punctations ( $n=2$, Figure 12f), and fingernail punctations $(n=3)$. Sherds decorated solely with rows of punctations on the rim may be from Mockingbird Punctated vessels, a common Titus phase utility ware on sites in the upper Sabine and Big Cypress stream basins. 


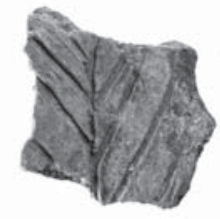

a

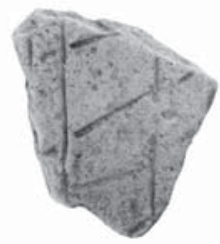

b

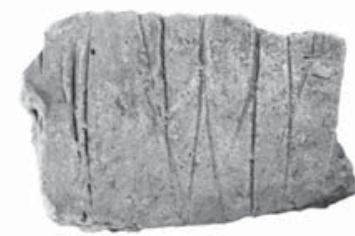

C

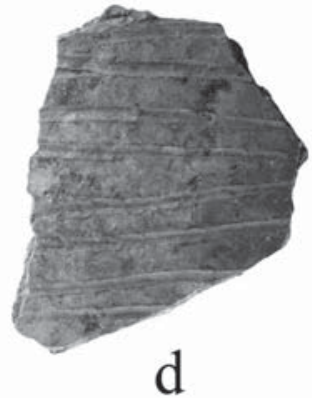

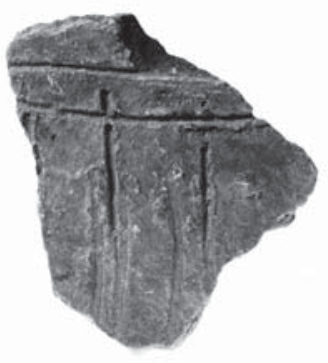

e

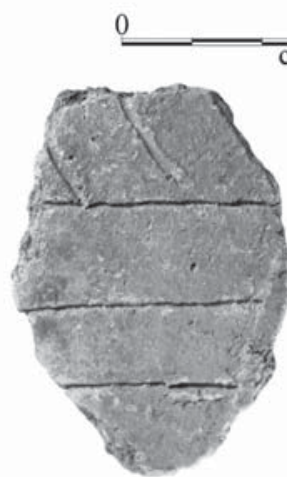

f

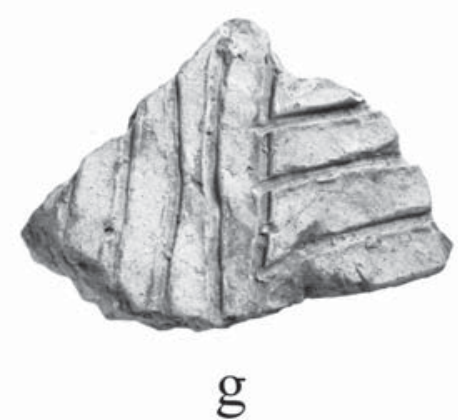

g

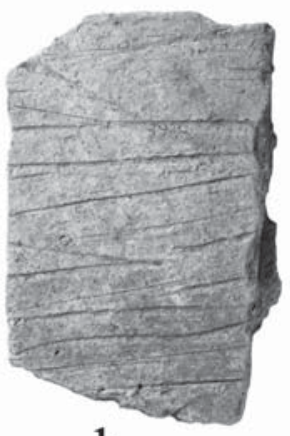

$\mathrm{h}$

Figure 10. Incised body sherds.
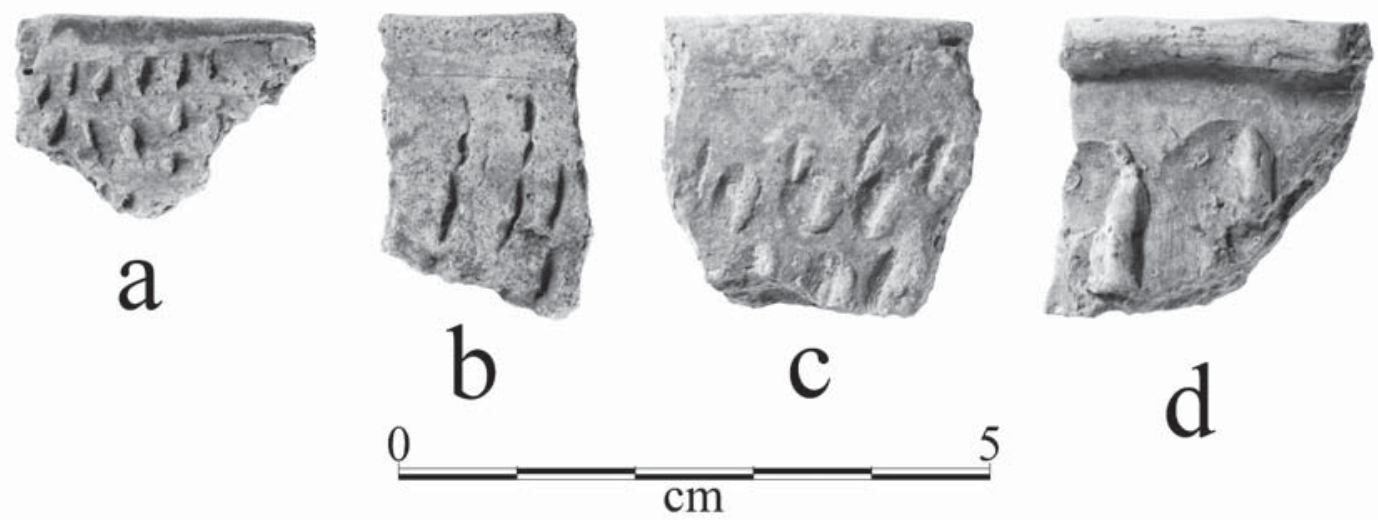

d

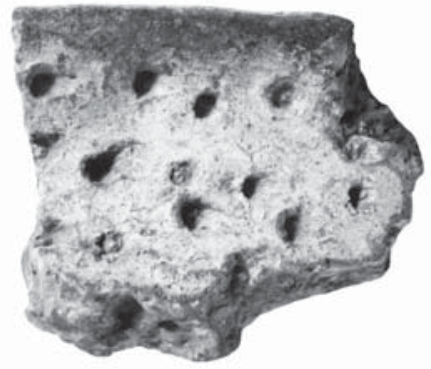

e

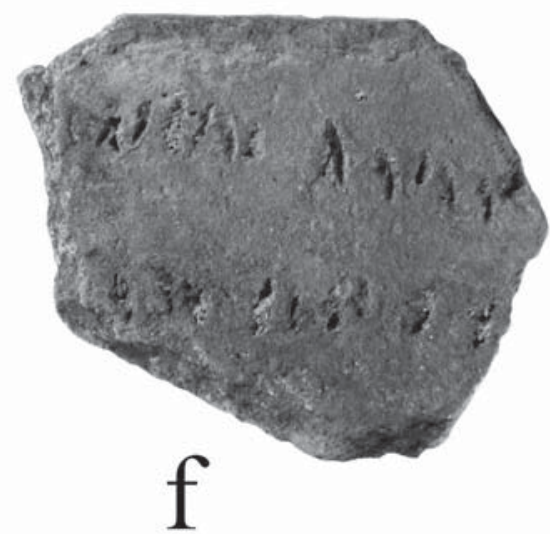

Figure 11. Tool punctated rim sherds. 

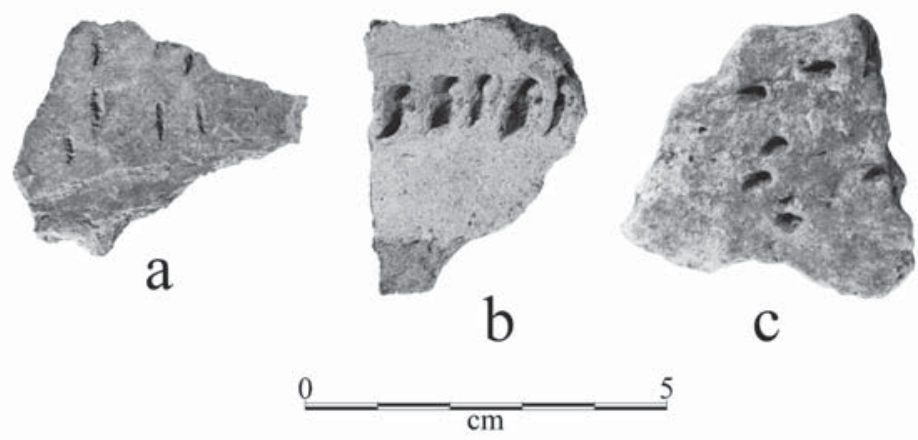

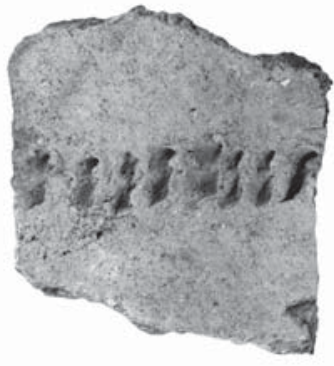

d

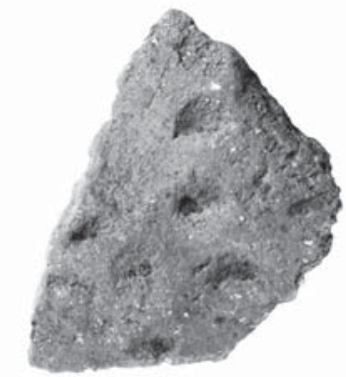

e

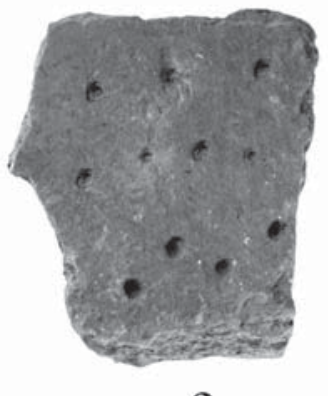

$\mathrm{f}$

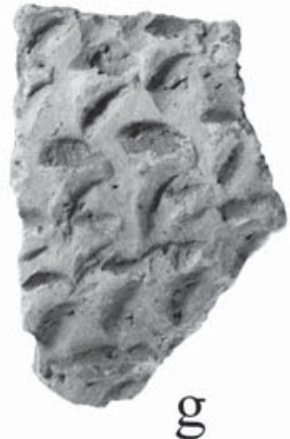

$\mathrm{g}$

Figure 12. Tool punctated rim and body sherds: c, rim sherd; a-b, d-g, body sherds.

\section{Incised-Punctated Sherds}

Incised-punctated sherds, likely from Maydelle Incised vessels, account for only $1.7 \%$ of the utility wares from the Sam D. Carpenter Bottom site. The rim sherds include four with a row of tool punctations under the lip and diagonal incised lines (Figure 13a), one with diagonal incised lines and a vertical row of tool punctations, another with horizontal incised lines and row of tool punctations placed through the lines, and one with a circular incised zone filled with tool punctations (Figure 13b).

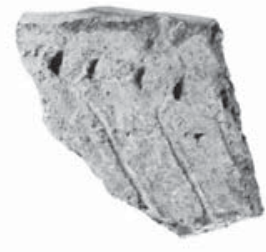

a

0

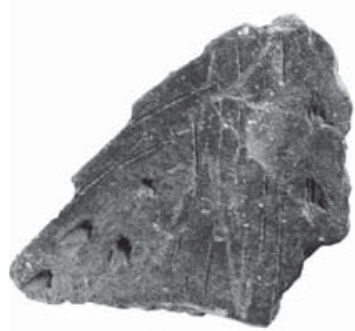

$\mathrm{C}$

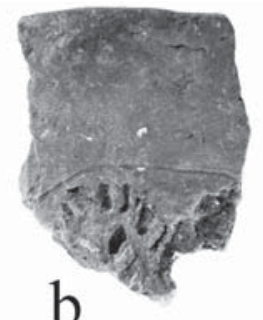

5

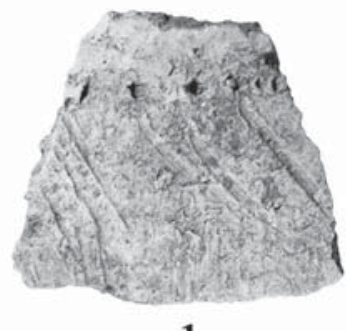

d
Figure 13. Incised-punctated rim and body sherds and Incised-punctated-brushed lower rim and body sherd: a-c, incised-punctated; $d$, incisedpunctated-brushed.
Two of the incised-punctated body sherds have rows of fingernail punctations adjacent to a straight incised line. A third body sherd, with bone temper, has sets of opposed diagonal incised lines, with the triangular area between the lines filled with tool punctations (see Figure 13c).

\section{Incised-Punctated-Brushed Sherds}

This lower rim-body sherd has a row of tool punctations on the lower part of the rim, followed by a series of short diagonal incised lines that extend to the rim-body juncture. The vessel body has vertical brushing marks (see Figure 13d).

\section{Appliqued Sherds}

Grog-tempered appliqued sherds have nodes or vertical fillets on the rim ( $n=2$, Figure 14a-b), as well as straight appliqued fillets $(\mathrm{n}=2)$ or ridges $(n=4)$ on the vessel body (Figure 14d). 


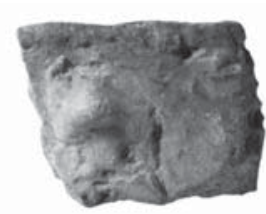

a

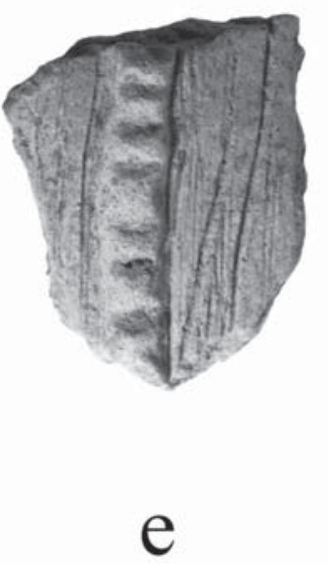

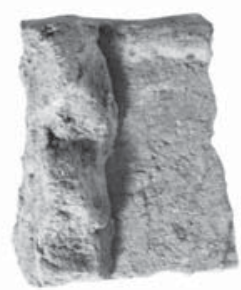

$\mathrm{b}$

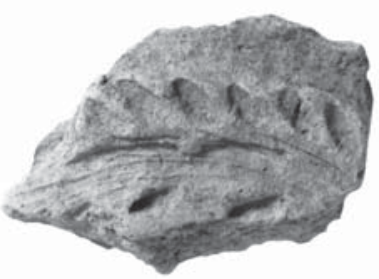

C

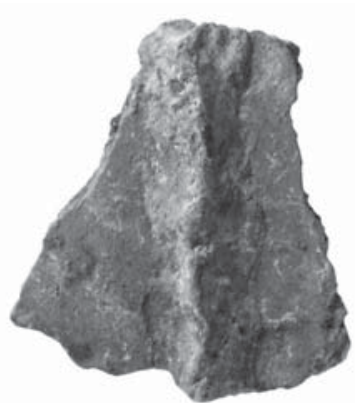

5 d

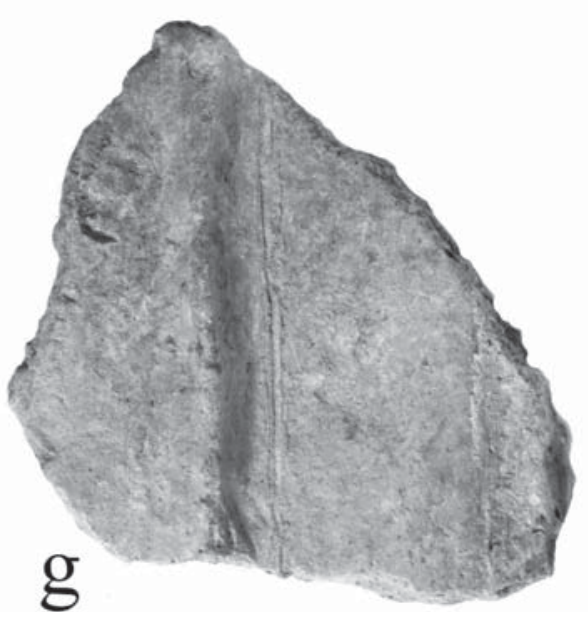

Figure 14. Rim and body sherds with appliqued elements, either by themselves, or together with other decorative elements: a-b, d, appliqued; c, appliqued-brushed (Harleton Appliqued); e, appliqued-brushedincised; f-g, incised-appliqued body sherds.

\section{Appliqued-Brushed Sherds}

One Harleton Appliqued jar sherd has a curvilinear appliqued fillet and curvilinear brushed marks between fillets (see Figure 14c). two other body sherds have either a straight appliqued fillet or an appliqued ridge adjacent to an area with parallel brushed marks.

\section{Appliqued-Brushed-Incised Sherds}

One body sherd is decorated with a straight appliqued fillet with parallel brushed-incised lines on either side of the fillet (see Figure 14e).

\section{Appliqued-Brushed-Punctated Sherds}

A single grog-tempered body sherd is decorated with a straight appliqued ridge adjacent to an area with parallel brushing, as well as a row of tool punctations.

\section{Appliqued-Incised Sherds}

The five appliqued-incised body sherds (all grog-tempered) in the assemblage have either straight appliqued fillets $(n=3)$ or straight appliqued ridges $(n=2$, see Figure $14 f-g)$. There are parallel, straight, or opposed incised lines on either one or both sides of the appliqued elements. 


\section{Neck Banded}

There are two grog-tempered sherds from a La Rue Banded jar (Suhm and Jelks 1962:Plate 47) in the utility wares. These jars have horizontal rows of neck banding on their rims.

\section{Ridged Sherds}

A single sherd from a grog-tempered Belcher Ridged jar (see Suhm and Jelks 1962:Plate 6) is in the collection; the sherd represents a trade vessel to Titus phase Caddo peoples. The sherd is from a vessel that has a series of vertically-oriented narrow ridges, with vertical brushing marks between the ridges. Belcher Ridged is the most common utility ware in Belcher phase components on the Red River in Northwest Louisiana (Kelley 2012:Table 14-1), and was made by Caddo potters between ca. A.D. 1500-1700.

\section{Plain Wares}

The plain wares from the site include 26 rims, 704 body sherds, and 45 flat and disk-shaped base sherds (see Table 1). The plain rims are from jars and bowls; the latter often have direct rims and exterior folded lips (Figure 15b, d-e).

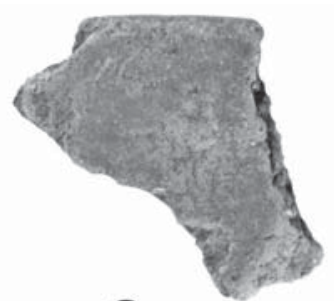

a

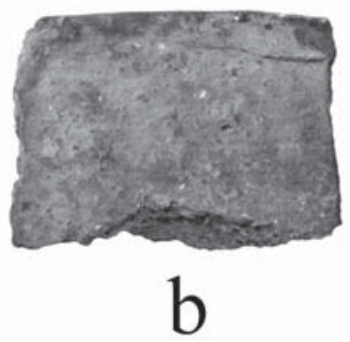

0
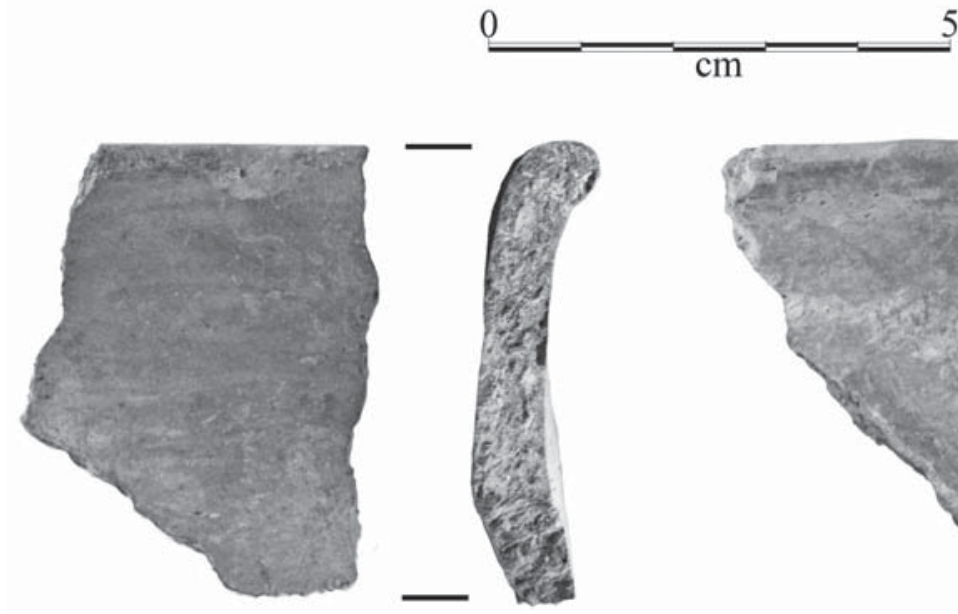

d

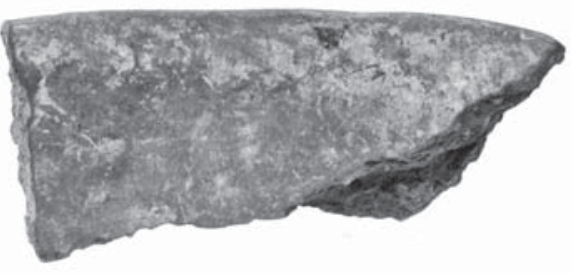

C
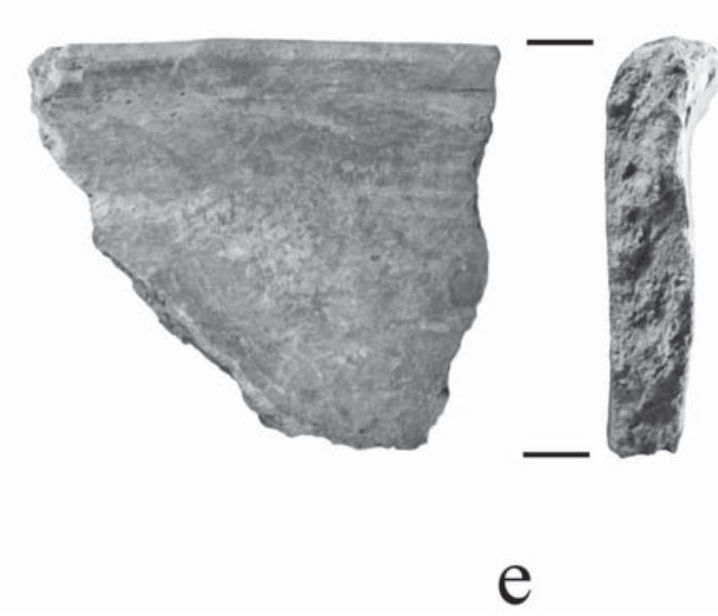

Figure 15. Plain ware rim sherds.

\section{Ceramic Pipe Sherds}

One elbow pipe stem sherd is in the ceramic collection. Such pipes were commonly made and used by Late Caddo groups in the Big Cypress Creek basin. 


\section{Daub and Mud dauber Nest}

The presence of daub ( $n=9$ pieces) and a mud dauber nest fragment in the collection suggests that there are preserved wattle and daub-covered Caddo wood structures at the site, or at least the burned evidence of their construction and use.

\section{Lithic Artifacts}

\section{Arrow points}

Nine arrow points are in the Sam D. Carpenter Bottom collection, three of the Maud type (Figure 16b, e-f) and six Perdiz points (Figure 16a, c-d, g-i). The proportions of arrow points suggest that the occupation here dates to the latter part of the earlier portion of the Titus phase in the Big Cypress Creek basin, from ca. A.D. $1500-1550$.

The Perdiz points are generally unifacially flaked (67\%) and made from chert $(83 \%)$; one of the Perdiz points is made from a local quartzite (see Figure 16c). Two of the Perdiz points are made from a local brown chert (see Figure 16a, d), but the other three are from Ouachita Mountains sources, including a gray chert (see Figure 16g) and a brownish-black Big Fork chert (see Figure 16h-i). The Maud arrow points are primarily unifacially flaked as well $(67 \%)$, but are all made from a local fine-grained quartzite; two of the three are of a heat-treated quartzite (see Figure 16b, f).
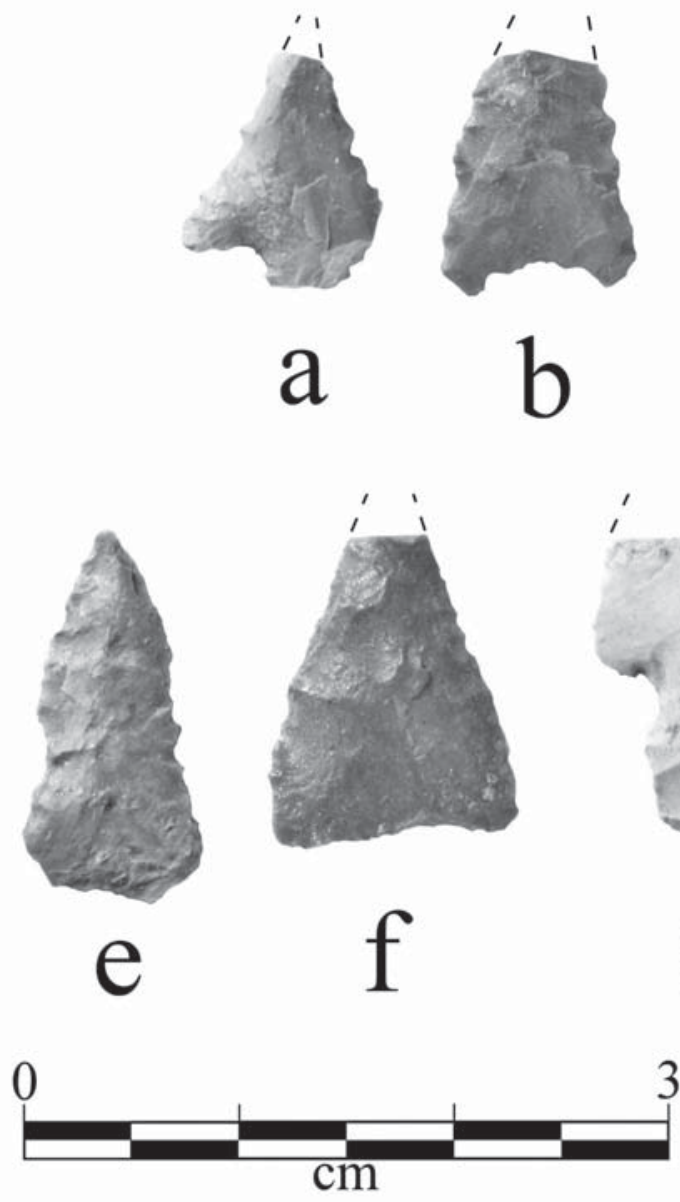
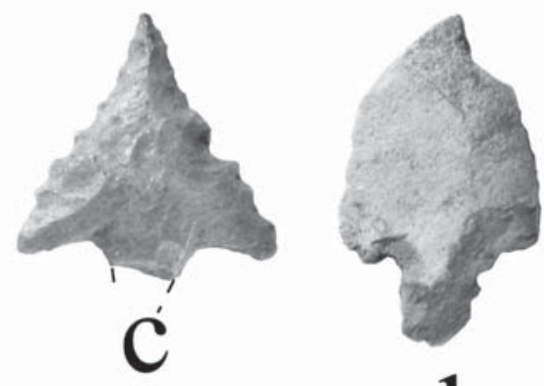

d
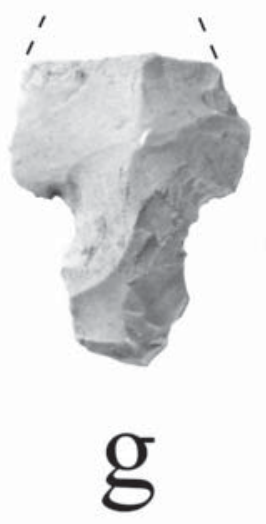

西

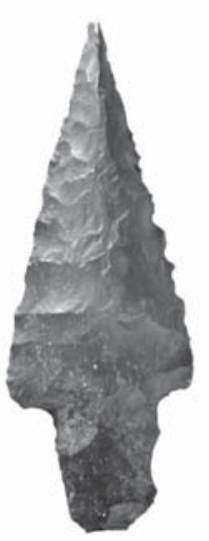

$\mathrm{h}$

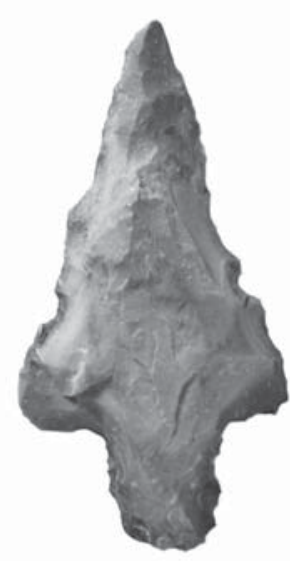

1

Figure 16. Arrow points: a, c-d, g-i, Perdiz; b, e-f, Maud. 


\section{Bifaces}

There are three small biface fragments from the Sam D. Carpenter Bottom site, obviously discarded during the manufacturing process. Two of the bifaces are on a local quartzite, but the third is on a non-local gray chert.

\section{Lithic debris}

Including four cores, there are 109 pieces of lithic debris in the surface collection. The cores (both single and multiple platform flake types) are on local raw materials: quartzite $(n=3)$ and yellow chert $(n=1)$. Both local and non-local lithic raw materials are represented in the lithic debris, indicating that tools were knapped from a variety of sources during the Caddo occupation. Local lithic raw materials comprise $89 \%$ of the lithic debris, including quartzite ( $\mathrm{n}=50$, or $54 \%$ of the local lithic debris); brown chert $(\mathrm{n}=31,33 \%)$; petrified wood $(n=4,4 \%)$; yellow chert $(n=4,4 \%)$; red chert $(n=2,2 \%)$; brown chalcedony $(n=1,1 \%)$; and brownish-red chert $(\mathrm{n}=1,1 \%)$. Non-local lithic raw materials $(11 \%)$ in the lithic debris include grayish-brown chert $(\mathrm{n}=4$, $33 \%$ of the non-local lithic debris); orange novaculite $(n=3,25 \%)$; greenish-gray quartzite $(n=2,17 \%)$; white chert $(\mathrm{n}=1,8 \%)$; gray chert $(\mathrm{n}=1,8 \%)$; and dark gray chert $(\mathrm{n}=1,8 \%)$. These materials likely all originated from raw material sources in the Ouachita Mountains of southeastern Oklahoma, and were probably also available in stream gravels of the Red River, about 70 miles north of the Sam D. Carpenter Bottom site.

There is a single unmodified quartzite cobble in the lithic assemblage. This is probably a cobble gathered as a source of raw material, but it was never reduced or knapped.

\section{Fire-cracked rocks}

Also in the collection are four pieces of quartzite fire-cracked rock. These are likely the product of the occasional use of a rock hearth or cooking fire.

\section{Ground stone tools}

There are five ground stone tools in the collection from the site. These include a ferruginous sandstone abrader with worn grooves on both sides of the tool, two ferruginous sandstone manos (grinding on both surfaces), a quartzite pitted stone with two pits on one surface, and a quartzite pestle fragment. These tools would have been used by Caddo peoples for wood and bone shaping and for the grinding and pulverizing of plant foods and seeds.

\section{ANALYSIS OF FAUNAL REMAINS FROM THE SAM D. CARPENTER BOTTOM SITE (41CP495)}

\section{LeeAnna Schniebs}

Surface investigations along Big Cypress Creek in Camp County, Texas, at the Late Caddo period Titus phase Sam D. Carpenter Bottom site (41CP495) included the collection of 92 faunal specimens. The sample weighs 335.2 grams, $53.2 \%$ of the sample is identifiable, and 15 bone fragments are burned. In general, the collection is very well preserved although 10 deer bones are rodent gnawed and two bone surfaces are exfoliated. Table 7 provides the number of specimens (NISP) in the Sam D. Carpenter Bottom site faunal collection, as well as the minimum number of individuals (MNI), number of burned bones, and the percent of the sample represented by each taxon. 
Table 7. Summary of taxonomic recovery from the Sam D. Carpenter Bottom site (41CP495).

\begin{tabular}{lllll}
\hline Taxon & NISP & MNI & Percent & No. Burned \\
\hline $\begin{array}{l}\text { Indeterminate (Vertebrata) } \\
\text { Softshell turtle (Trionyx sp.) }\end{array}$ & 2 & - & 2.2 & - \\
Indeterminate turtle (Testudinata & 1 & 1 & 1.1 & - \\
Turkey (Meleagris gallopavo) & 1 & - & 1.1 & 1 \\
Raccoon (Procyon lotor) & 1 & 1 & 1.1 & - \\
White-tailed deer & & 1 & 1.1 & - \\
(Odocoileus virginianus) & 45 & 2 & 48.9 & 5 \\
Small mammal (small Mammalia) & 1 & - & 1.1 & - \\
Large mammal (large Mammalia) & 40 & - & 43.4 & 9 \\
\hline Total & 92 & 5 & 100.0 & 15 \\
\hline
\end{tabular}

The recovery of deer, turtles, turkey, and raccoon is typical of Late Caddo faunal assemblages in East Texas. These animals prefer wooded edges and areas in close proximity to aquatic habitats, and are important protein supplements of the Caddo diet. They also provide materials used for non-food items as well, such as hides for clothing, feathers for decoration, and bones for tools. There are a minimum of two deer in the collection based on the identification of two right petrous bones (a hard portion of bone surrounding the inner ear). At least one of the individuals is immature indicated by four bones that are lacking epiphyseal fusion. The unidentifiable large mammal bones are small fragments from larger elements, and are likely the remains of deer. Table 8 lists only the identifiable elements in the Sam D. Carpenter Bottom site sample.

The deer elements recovered are dominated by leg bones, but also includes nine cranial elements, three rib and four vertebra fragments. The absence of scapula and pelvis bones may be the result of collection methods, or possibly that the majority of the torso was processed in another location. There are cut marks visible on the humerus bone and one of the femur fragments, which is indicative of butchering. Additional investigations at the Sam D. Carpenter Bottom site would provide more information about Late Caddo subsistence practices, such as animal hunting and processing information. The faunal remains from this site can be considered subsistence debris.

\section{MUSSEL SHELL}

Approximately 20 pieces of freshwater mussel shell are in the surface collection. Their preservation is indicative of the preservation of organically enriched archaeological deposits (i.e., midden deposits) at the site, or at least in the surface collection area. 
Table 8. Composition of identified elements in the Sam D. Carpenter Bottom site faunal collection.

\begin{tabular}{|c|c|c|}
\hline Taxon & Element & $\mathrm{N}$ \\
\hline Softshell Turtle & pelvis fragment & 1 \\
\hline Indeterminate Turtle & shell fragment & 1 \\
\hline Turkey & tarsometatarsus fragment & 1 \\
\hline Raccoon & humerus fragment & 1 \\
\hline \multirow[t]{18}{*}{ Deer } & antler fragment & 2 \\
\hline & cranial fragment & 4 \\
\hline & occipital condyle & 1 \\
\hline & petrous & 2 \\
\hline & rib fragment & 3 \\
\hline & vertebra fragment & 4 \\
\hline & humerus fragment & 1 \\
\hline & radius fragment & 2 \\
\hline & ulna fragment & 3 \\
\hline & metacarpal fragment & 1 \\
\hline & calcaneus fragment & 2 \\
\hline & navicular cuboid & 2 \\
\hline & metatarsal fragment & 2 \\
\hline & tibia fragment & 5 \\
\hline & femur fragment & 4 \\
\hline & metapodial fragment & 4 \\
\hline & scaphoid & 1 \\
\hline & phalanx & 2 \\
\hline Total Identifiable Bone & & 49 \\
\hline
\end{tabular}

\section{SUMMARY AND CONCLUSIONS}

The Sam D. Carpenter Bottom site (41CP495) appears to be a single component Late Caddo period, Titus phase domestic site located in a bottomland setting in the Big Cypress Creek valley. A large sample of plain and decorated sherds from bowls, carinated bowls, compound bowls, bottles, and jars were collected from the surface of the site by Robert L. Turner, Jr., and they provide an indication of the composition of Titus phase domestic assemblage in the region; the vessels are almost exclusively tempered with grog, with the minor use of burned bone. Utility wares comprise almost $77 \%$ of the decorated sherds (and sherds with brushing account for $53 \%$ of the decorated sherds in the assemblage), with the remainder of the decorated sherds from engraved, engraved/red-slipped, and red-slipped fine ware sherds. Plain ware rims indicate that plain vessels are also a substantial part of the assemblage.

The utility wares are dominated by jars with brushed bodies and rims (likely from Bullard Brushed and Karnack Brushed-Incised vessels as well as other utility wares with brushed bodies) as well as jars with incised decorations, including diagonal opposed motifs from Maydelle Incised jars, as well as punctated rims. At least one sherd is from a Harleton Appliqued vessel. The utility wares as a whole more closely resemble eastern Titus phase sites in the Big Cypress Creek heartland (Fields and Gadus 2012:71; Perttula and Sherman 2009) 
because of the quantities of brushed sherds and the absence of neck banded utility wares. The fine wares, on the other hand, from the Sam D. Carpenter Bottom site are more like western Titus phase sites in the Big Cypress Creek heartland because red-slipped sherds are common in the assemblage, and the Ripley Engraved carinated bowl sherds have scroll and scroll and circle motifs, while sherds with pendant triangle elements (i.e., excised pendant triangles and central diamonds) are mostly absent (Perttula and Sherman 2009:400), although there are a few sherds with hatched or excised pendant triangles, generally associated with scroll motifs. These patterns in the Ripley Engraved motif, and the occurrence of both Maud and Perdiz points, also suggests that the site dates sometime prior to ca. A.D. 1550, perhaps from ca. A.D. 1500-1550, after which this motif became more prevalent in Titus phase ceramic assemblages along with Maud and Talco arrow points (see Perttula 1992:Appendix 1). The three obvious trade ware sherd in the surface-collected assemblage are shell-tempered rim and body sherds that may be from a Red River McCurtain phase Caddo fine ware vessel or vessels along with a Belcher Ridged body sherd from a Belcher phase utility ware vessel.

\section{ACKNOWLEDGMENTS}

I appreciate the opportunity provided by Robert L. Turner, Jr. and Bo Nelson to study the surface collections from the Sam D. Carpenter Bottom site. Lance Trask prepared the figures for this article.

\section{REFERENCES CITED}

Fields, R. C. and E. F. Gadus

2012 The Pine Tree Mound Site and the Archeology of the Nadaco Caddo. Bulletin of the Texas Archeological Society 83:23-80.

Kelley, D. B.

2012 The Belcher Phase: Sixteenth- and Seventeenth-Century Caddo Occupation of the Red River Valley in Northwest Louisiana and Southwest Arkansas. In The Archaeology of the Caddo, edited by T. K. Perttula and C. P. Walker, pp. 411-430. University of Nebraska Press, Lincoln.

Perttula, T. K.

1992 “The Caddo Nation": Archaeological and Ethnohistoric Perspectives. University of Texas Press, Austin.

2012 The Character of Fifteenth- to Seventeenth-Century Caddo Communities in the Big Cypress Creek Basin of Northeast Texas. In The Archaeology of the Caddo, edited by T. K. Perttula and C. P. Walker, pp. 363-410. University of Nebraska Press, Lincoln.

2013 The Sam D. Carpenter Garden Plot Site (41CP496), Camp County, Texas. Journal of Northeast Texas Archaeology 40:47-52.

Perttula, T. K. and D. L. Sherman

2009 Data Recovery Investigations at the Ear Spool Site (41TT653), Titus County, Texas. Document No. 070205. PBS\&J, Austin.

Perttula, T. K., M. B. Trubitt, and J. S. Girard

2012 The Use of Shell-Tempered Pottery in the Caddo Area of the Southeastern United States. Southeastern Archaeology 30(2):242-267.

Suhm, D. A., and E. B. Jelks (editors)

1962 Handbook of Texas Archeology: Type Descriptions. Special Publication No. 1, Texas Archeological Society, and Bulletin No. 4, Texas Memorial Museum, Austin. Reprinted in 2009, Gustav's Library, Davenport, Iowa.

Thurmond, J. P.

1990 Archeology of the Cypress Creek Drainage Basin, Noortheastern Texas and Northwester Louisiana. Studies in Archeology 5. Texas Archeological Research Laboratory, The University of Texas at Austin. 
